\title{
Analisis Kemampuan Literasi Digital Orang Tua Anak Usia Dini di Kecamatan Tampan Kota Pekanbaru Riau
}

\author{
Nur Ain ${ }^{1]}$, Ria Novianti ${ }^{2]}$, Yeni Solfiah ${ }^{3]}$, Enda Puspitasari ${ }^{4]}$ \\ Universitas Riau \\ E-mail: ${ }^{1}$ ain.nursyahn245@gmail.com \\ ${ }^{2}$ rianovianti.rasyad@gmail.com \\ ${ }^{3}$ habildaulaey@yahoo.co.id \\ 4enda.puspitasari@gmail.com
}

\begin{abstract}
Abstrak
Literasi Digital suatu kemampuan yang perlu dimiliki oleh orang tua, untuk memahami dan menggunakan informasi dari berbagai sumber digital yang ada. Pada masa pandemi seperti saat ini, keharusan anak untuk melakukan pembelajaran dari rumah mau tidak mau mengharuskan orang tua untuk ikut terjun langsung dalam proses belajar mengajar anak-anaknya dirumah, namun pada kenyataanya tidak semua orang tua memiliki kemampuan literasi digital yang baik, bahkan beberapa diantaranya mengakui bahwa anak lebih bisa menggunakan teknologi digital terutama gadget selangkah lebih maju dari orang tua. Penelitian ini bertujuan untuk mengetahui kemampuan literasi digital orang tua anak usia dini di Kecamatan Tampan Kota Pekanbaru Riau. Metode penelitian ini adalah deskriptif kuantitatif yang dilaksanakan di Kecamatan Tampan Kota Pekanbaru Riau. Populasi dalam penelitian ini adalah sebanyak 40 orang tua yang memiliki anak usia dini di Kecamatan Tampan Kota Pekanbaru yang dipilih secara acak. Penelitian ini menggunakan kuesioner kemampuan literasi digital orang tua dengan menggunakan Teori Instant Digital Competence Assessment (Idca) sebagai instrumen yang dapat diukur dengan menggunakan skala likert. Hasil penelitian ini menunjukkan bahwa kemampuan literasi digital orang tua anak usia dini di Kecamatan Tampan Kota Pekanbaru Provinsi Riau berada pada kategori "Rendah" yaitu dengan persentase 31\%. Penelitian ini memberikan rekomendasi kepada orang tua agar dapat lebih memperhatikan betapa pentingnya kemampuan literasi digital bagi diri sendiri maupun orang lain terutama anak usia dini di zaman modern ini.
\end{abstract}

Kata kunci : Literasi Digital, Teori Instant DCA, Orang Tua, Anak Usia Dini

\section{Analysis of Early Childhood Parents' Digital Literacy Ability in Tampan District Pekanbaru City of Riau}

\begin{abstract}
Digital Literacy is an ability that parents need to understand and use information from various existing digital sources. During a pandemic like this time, the obligation of children to learn from home inevitably requires parents to participate directly in the
\end{abstract}


teaching and learning process of their children at home, but in fact not all parents have good digital literacy skills, even some of them admit that children are more able to use digital technology, especially gadgets, one step ahead of parents. This study aims to determine the digital literacy skills of parents of early childhood in Tampan District, Pekanbaru Riau City. This research method is quantitative descriptive which was carried out in Tampan District, Pekanbaru Riau City. The population in this study were 40 parents who has early childhood in the Tampan District, Pekanbaru City who were randomly selected. This study uses a questionnaire of parents' digital literacy skills using the Instant Digital Competence Assessment (Idca) theory as an instrument that can be measured using a Likert scale. The results of this study indicate that the digital literacy skills of early childhood parents in Tampan District, Pekanbaru City, Riau Province are in the "Low" category with a percentage of 31\%. This study provides recommendations for parents to pay more attention to the importance of digital literacy skills for themselves and others, especially early childhood in modern times.

Keywords: Digital Literacy, Instant DCA Theory, Parents, Early Childhood

\section{PENDAHULUAN}

Saat ini seiring dengan berjalannya waktu, perkembangan teknologi dan informasi yang semakin pesat telah membawa kita sebagai generasi saat ini masuk ke dalam dunia digital. Literasi digital pada saat ini sudah menjadi hal yang tidak asing lagi dan lumrah bagi generasi saat ini. Bahkan pada saat ini salah satu alternatif digital yang terus berkembang dan dapat kita jumpai di kehidupan sehari- hari adalah dengan beralihnya bahan bacaan fisik menjadi digital seperti jika dulu jika ingin mengetahui ingin mengetahui seputar informasi terbaru bisa di dapatkan dari koran atau surat kabar dan majalah, pada saat ini informasi bisa di dapatkan dengan sangat mudah di genggaman melalui internet dan smartphone.

Dalam kehidupan sehari-hari pada saat ini, pengguna internet yang masih berada di bawah umur dapat dengan mudah kita jumpai di tempat tempat umum seperti di lingkungan rumah, taman bermain, pusat perbelanjaan atau tempat rekreasi sekalipun bahkan biasanya dapat di jumpai anak usia dini yang sedang terlihat sibuk dengan gadget yang dimilikinya dengan berbagai macam aplikasi-aplikasi atau permainan yang ada di dalam gadgetnya. Kebanyakan anak usia dini yang berada pada usia 4 sampai dengan 7 tahun sudah mampu dan dapat menggunakan berbagai fitur dari aplikasi-aplikasi yang ada serta dapat mengoperasikan gadgetnya sendiri secara otodidak atau tanpa bantuan orang lain, kemampuan ini biasanya anak dapatkan hanya dengan melihat dan memperhatikan orang yang ada disekitar anak seperti ayah, ibu, kakak atau yang terdekat dengan anak di lingkungannya pada saat sedang menggunakan smartphone atau perangkat digital lainnya. Maka, dari kebiasaan anak untuk dapat dengan mudah merekam dan meniru kegiatan yang dilakukan orang disekitarnya inilah yang membuat anggota keluarga khususnya para orang 
tua yang memiliki anak usia dini, harus mampu untuk dapat langsung mengawasi serta membimbing anak-anak pada saat anak sedang menggunakan perangkat digital seperti gadget, agar nantinya diharapkan dengan adanya bimbingan dan pengawasan dari orang tua tersebut, anak dapat memanfaatkan dan menggunakan internet dengan positif dan baik.

Pada saat ini dapat kita jumpai dengan mudah berbagai macam kajian mengenai penggunaan internet dan keluarga yang biasanya berkisar pada suatu penggambaran sebuah tren penggunaan internet dan teknologi digital dalam masyarakat, seperti banyaknya waktu yang di alokasikan pada saat sedang menggunakan internet, bagaimana sikap anak dan orang dewasa dalam hal ini orang tua pada saat berhadapan langsung atau menggunakan internet, dan juga bagaimana internet dapat mengubah fungsi sosial dalam keluarga pada kehidupan digital saat ini ini Hughes \& Hans dalam (Kurnia, Novi, Engelbertus Wendratama, 2017).

Dengan demikian, Literasi digital dalam keluarga memiliki peran yang sangat penting untuk anak usia dini jika di terapkan dengan baik. Keluarga sebagai orang yang paling dekat dengan anak pada saat di rumah dalam hal ini adalah orang tua, kakak, adik yang berada di lingkungan anak diharapkan harus mampu untuk dapat memberikan contoh dan pemahaman yang baik untuk menggunakan teknologi digital yang ada dengan sebaik- baiknya. Menurut (Davidson, 2012) untuk bisa menggunakan internet dengan positif, anak-anak sangat memerlukan adanya bimbingan dan pengawasan dari orang tua. Oleh sebab itu, untuk dapat melakukan pembimbingan dan pengawasan terhadap anak, terlebih dahulu orang tua di tuntut untuk dapat memiliki kemampuan yang baik dalam hal pengetahuan ataupun emosi pada saat sedang menggunakan atau mengakses berbagai macam fitur- fitur dan informasi terpercaya maupun segala macam hiburan dari media digital yang ada di internet. Pembimbingan ini merupakan sebuah bentuk nyata dari betapa pentingnya kemampuan literasi digital yang orang tua miliki yang nantinya dapat orang tua tularkan dari lingkungan keluarga kepada anak-anak khususnya anak usia dini.

Berbagai kajian mengenai internet dan keluarga biasanya berkisar pada penggambaran suatu tren penggunaan internet, seperti halnya waktu yang saat ini dapat di alokasikan dengan menggunakan internet, bagaimana anak dan orang dewasa menggunakan internet untuk menunjang kehidupan sehari-hari, dan juga bagaimana internet dapat mengubah fungsi sosial dalam keluarga di kehidupan digital dewasa ini, Hughes \& Hans dalam (Novi Kurnia, dkk, 2017). Literasi digital merupakan suatu kemampuan yang harus dimiliki untuk memahami dan menggunakan informasi dari berbagai sumber digital yang disajikan melalui komputer.

Dari pendapat kedua ahli tersebut maka dapat disimpulkan bahwa literasi digital adalah sebagai suatu kemampuan yang dimiliki individu yang mana dalam hal ini khususnya para orang tua untuk dapat memahami dan menggunakan berbagai teknologi informasi digital yang ada dengan sebaik-baiknya.

Setelah mengetahui mengenai literasi digital secara keseluruhan, 
selanjutnya adalah Literasi digital dalam keluarga yang dalam penelitian ini memiliki peran yang sangat penting dalam kehidupan sehari-hari untuk anak usia dini. Keluarga dalam artian orang tua, kakak maupun adik yang ada di lingkungan sekitar anak harus mampu memberikan contoh dan pemahaman yang baik untuk menggunakan teknologi digital yang ada.

Sebelum mengembangkan sebuah cara baru yang dapat digunakan untuk mendidik anak di era digital ini, orang tua sangat perlu memiliki pemahaman mengenai seberapa pentingnya kemampuan literasi digital dalam keluarga anak usia dini. Pemahaman keluarga khususnya para orang tua untuk dapat menggunakan teknologi digital dengan sebaik- baiknya yang masih kurang menjadi suatu permasalahan yang harus di perhatikan. Masih banyak anggota keluarga terutama orang tua yang belum mengetahui bahwa teknologi digital juga dapat digunakan untuk mengakses berbagai kegiatan-kegiatan pembelajaran yang menarik dan tutorialtutorial yang dapat orang tua gunakan untuk membantu mengatasi suatu permasalahan yang biasanya ditemukan dalam kehidupan sehari-hari, bukan hanya untuk sekedar menonton film ataupun untuk digunkaan bermain game online yang di maksudkan agar anak dapat duduk tenang dan fokus dengan gadgetnya.

Anak-anak dalam hal ini sangat memerlukan bimbingan dan arahan dari orang tua untuk dapat menggunakan media digital dengan bijaksana. Maka dari itu orang tua perlu memahami nilai utama mengenai dunia digital yang sedang menyetir kehidupan sehari-hari kita saat ini. Adapun untuk dapat menggunakan media digital dengan bijaksana dan positif terdapat tiga nilai penting yaitu adanya kreativitas, kolaborasi dan berfikir (Kurnia, Novi, Engelbertus Wendratama, 2017)

Data menunjukkan sebanyak $12 \%$ anak-anak kebanyakan telah mengenal teknnologi digital khususnya internet pada saat menginjak usia 5 tahun, sebanyak $4 \%$ anak mengenal teknologi digital pada saat menginjak usia 4 tahun, dan sebanyak $1 \%$ diantaranya telah mengenal teknologi digital pada saat berada di usia 3 tahun (Candra, 2013), Dari temuan penelitian tersebut maka dapat diketahui dan terlihat bahwa pengguna internet yang masih berada pada usia yang sangat muda dan bahkan sebanyak 1\% yang merupakan anak yang berusia 3 tahun telah mengenal teknologi digital pada usia balita anak-anak telah dikenalkan dengan internet. (Sucipto \& Nuril, H, 2016) di dalam penelitiannya menyatakan bahwa sebanyak 54\% orang tua memperbolehkan anak yang memiliki usia 3-4 tahun untuk menggunakan gadget dengan berbagai alasan seperti agar anak dapat mengikuti perkembangan zaman yang semakin maju dan berkembang dengan mengenal teknologi sejak dini, agar anak tidak rewel pada saat orang tuanya sibuk mengerjakan pekerjaan rumah sehingga tidak dapat selalu bermain dengan anak dan teman-teman anak yang berada disekitarnya (lingkungan rumah atau lingkungan sekolah) kebanyakan sudah memiliki gadget sehingga orang tua anak yang belum memiliki gadget tersebut berpikiran untuk memberikan gadget kepada sang anak.

Dari data tersebut maka dapat disimpulkan bahwa kebanyakan para 
orang tua memberikan gadget kepada anak usia dini agar anak tidak rewel dan tidak mengganggu pekerjaan yang sedang dilakukan oleh orang tuanya pada saat dirumah sehingga orang tua dapat dengan leluasa menyelesaikan pekerjaannya tanpa adanya gangguan dari anak

Berdasarkan observasi yang telah dilakukan oleh peneliti di dalam lingkungan keluarga dan lingkungan sekitar tempat tinggal peneliti pada orang tua yang memiliki anak usia 3 sampai dengan usia 6 tahun, kebanyakan anakanak sudah memiliki gadgetnya sendiri yang khusus diberikan orang tuanya untuk anak gunakan ketika orang tuanya sedang mengerjakan pekerjaannya di rumah. Kebanyakan anak-anak yang berada pada usia 3 sampai dengan usia 4 tahun akan diberikan gadget oleh orang tuanya yang sebelumnya orang tua telah memutar film kartun dan memberikannya ke anak dan kemudian orang tua akan meninggalkan anak asik dengan film kartunnya. sedangkan untuk anak yang berusia 4 sampai dengan berusia 6 tahun kebanyakan dari mereka sudah dapat mengakses sendiri apa yang ingin anak mainkan atau anak tonton yang kebanyakan tanpa adanya pengawasan dari orang tuanya secara langsung. Bahkan biasanya anak akan berkumpul dengan temannya yang lain untuk menunjukkan games yang sedang mereka sukai atau mainkan.

Dalam situasi diatas terkadang orang tua tidak mengetahui apa yang anak akses pada saat sedang menggunakan gadget, yang seharusnya orang tua hendaknya mendampingi anak pada saat menggunakan gadget.

Dari penjelasan diatas maka timbul sebuah pertanyaan bagaimakah tingkat kemampuan literasi digital orang tua anak usia dini di Kecamatan Tampan Kota Pekanbaru Riau itu sendiri, berdasarkan dari hasil observasi yang sebelumnya telah dilakukan oleh peneliti di dalam lingkungan keluarga dan lingkungan sekitar tempat tinggal peneliti yang berada di Kecamatan Tampan, seperti pada masa pandemic covid seperti saat ini, keharusan anak untuk melakukan pembelajaran dari rumah mau tidak mau mengharuskan orang tua untuk ikut terjun langsung dalam proses belajar mengajar yang dilakukan anak-anaknya dirumah.

Bagi para orang tua yang masih memiliki kemampuan literasi digital yang rendah dipastikan akan mengalami kesulitan pada saat mendapatkan dan mencari tugas-tugas yang diberikan oleh guru di internet untuk kemudian digunakan dan untuk mendampingi anak pada saat sedang belajar, sehingga kebanyakan mereka hanya mengharapkan apa yang guru tugaskan kepada anak. Sedangkan bagi orang tua yang memiliki kemampuan literasi yang cukup baik, mereka akan mencari hal-hal lainnya yang dapat anak kerjakan dengan mengandalkan beberapa aplikasi pintar yang dapat orang tua download secara gratis sehingga waktu anak selama dirumah tidak terbuang sia-sia hanya untuk bermain saja. Oleh sebab itu, dengan adanya pemahaman literasi digital para orang tua yang memiliki anak usia dini diharapkan mampu mempermudah urusan para orang dalam membuat media digital sebagai sarana belajar yang menarik dan menyenangkan bagi anak dan untuk mendampingi anak dalam menggunakan internet.

Dari penjelasan latar belakang permasalahan yang telah dibahas diatas, 
maka untuk selanjutnya perlu dilakukan penelitian yang bertujuan untuk mengetahui kemampuan literasi digital dalam keluarga anak usia dini di Kecamatan Tampan Kota Pekanbaru Riau.

\section{METODE}

Penelitian ini dilakukan pada para orang tua yang memiliki anak usia dini yang tinggal di Kecamatan Tampan Kota Pekanbaru Riau dengan populasi sebanyak 40 orang tua anak usia dini yang dipilih secara acak yang tinggal dengan rentang umur orang tua antara 25 - 40 tahun yang memiliki anak usia 3-6 tahun, dengan tingkat pendidikan SMA \& S1. Barikut adalah data orang tua sebagai responden sebagai berikut:

Tabel 1. Data responden orang tua yang memiliki anak usia dini di Kecamatan Tampan Kota Pekanbaru Riau

\begin{tabular}{cccccc}
\hline $\begin{array}{c}\text { Usia } \\
\text { Orang } \\
\text { Tua }\end{array}$ & F & $\begin{array}{c}\text { Usia } \\
\text { Anak }\end{array}$ & F & $\begin{array}{c}\text { Tingkat } \\
\text { Pendidikan }\end{array}$ & F \\
\hline $25-$ & 7 & 3 & 10 & S1 & 8 \\
\hline 30 & 7 & 4 & 11 & SMA & 32 \\
\hline $31-35$ & 29 & 4 & & \\
\hline $36-40$ & 4 & 5 & 15 & & \\
\hline $41-50$ & 0 & 6 & 4 \\
\hline \multicolumn{7}{c}{ Jenis penelitian yang digunakan } \\
di dalam penelitian ini adalah deskriptif \\
kuantitatif. Penelitian deskriptif \\
merupakan sebuah metode penelitian \\
yang menggambarkan objek sesuai \\
dengan apa adanya. Penelitian ini \\
dilakukan dengan tujuan untuk \\
menggambarkan secara sistematis fakta \\
dan karakteristik objek atau subjek yang \\
diteliti secara tepat Metode kuantitatif \\
adalah metode penelitian yang datanya
\end{tabular}

berupa angka yang digunakan untuk mengukur suatu subjek atau objek penelitian. Penelitian ini dilakukan dengan mengumpulkan data yang berupa angka kemudian hasil dari penelitian digambarkan dan diinterpretasikan sesuai dengan hasil pengukuran.

Dalam penelitian ini data yang digunakan adalah data yang bersifat kuantitatif karena dinyatakan dengan angka-angka yang menunjukkan nilai terhadap suatu variabel. Penelitian ini merupakan penelitian dengan satu variabel yaitu kemampuan literasi digital. Adapun sumber data yang digunakan dalam penelitian ini adalah berupa data primer. Data primer adalah data yang diambil langsung dari responden melalui kuesioner berbasis online yang dibagikan ke responden dan instrumen yang digunakan adalah dalam bentuk kuesioner/angket berbasis online untuk mendapatkan informasi yang diperlukan dari responden.

Hasil kuesioner tersebut nantinya dapat berupa tabel frekuensi yang memiliki persentase yang dapat diukur dengan menggunakan skala likert, penulis memberikan 5 alternatif jawaban kepada responden dengan skala 1 sampai 5.

\begin{tabular}{|c|c|c|c|}
\hline $\begin{array}{c}\text { Pernyataan } \\
\text { Positif }\end{array}$ & Skor & $\begin{array}{c}\text { Pernyataan } \\
\text { Negatif }\end{array}$ & Skor \\
\hline $\begin{array}{c}\text { Sangat Sering } \\
\text { (SS) }\end{array}$ & 5 & $\begin{array}{c}\text { Sangat } \\
\text { Sering (SS) }\end{array}$ & 1 \\
\hline Sering $(\mathrm{S})$ & 4 & Sering $(\mathrm{S})$ & 2 \\
\hline $\begin{array}{l}\text { Cukup Sering } \\
\text { (CS) }\end{array}$ & 3 & $\begin{array}{c}\text { Cukup } \\
\text { Sering (CS) }\end{array}$ & 3 \\
\hline $\begin{array}{c}\text { Kadang - } \\
\text { Kadang (KK) }\end{array}$ & 2 & $\begin{array}{c}\text { Kadang - } \\
\text { Kadang } \\
\text { (KK) }\end{array}$ & 4 \\
\hline $\begin{array}{l}\text { Tidak Pernah } \\
\text { (TP) }\end{array}$ & 1 & $\begin{array}{c}\text { Tidak } \\
\text { Pernah (TP) }\end{array}$ & 5 \\
\hline
\end{tabular}


Data yang telah dikumpulkan sebelumnya dilakukan uji coba dengan cara melakukan uji validitas dan uji reliabilitas untuk mencari tahu valid atau tidaknya instrumen penelitian yang digunakan. Uji validitas dilakukan untuk mengetahui sejauh mana alat ukur yang disusun mampu mengukur indikator yang hendak diukur dan dianalisis dengan menggunakan standar Masrum dalam (Sugiyono, 2014), apabila dianggap memenuhi syarat jika $r=>0,361$ (untuk $n$ $=30$ orang). Untuk melakukan uji validitas data peneliti menggunakan SPSS for windows ver 22. Adapaun data yang diolah dalam penelitian ini adalah data kemampuan literasi digital orang tua anak usia dini di Kecamatan Tampan Kota Pekanbaru Provinsi Riau.

Sebelum angket digunakan terlebih adahulu penulis melakukan uji coba angket kepada beberapa orang tua yang tinggal di Kecamatan Tampan untuk memperoleh data yang valid dengan menyebarkan angket tersebut dengan 30 item pernyataan kepada 20 responden. Setelah angket dilakukan uji cobs ternyata dari total 30 item terdapat 7 item yang tidak valid yaitu item nomor 2 9, 10, 11, 24, 29 dan karena $r$ hitung $<\mathrm{r}$ tabel atau $\mathrm{r}$ hitung < 0,361 maka item yang tidak valid tersebut selanjutnya akan dibuang, dan kemudian peneliti kembali melakukan penyebaran angket yang terdiri dari 23 item pertanyaan kepada orang tua anak usia dini di Kecamatan Tampan Pekanbaru Riau.

Sedangkan untuk hasil dari Uji reliabilitas atau uji keandalan suatu instrument penelitian yang merupakan pengujian untuk mengetahui tingkat konsistensi suatu instrument yang akan dianalisis dengan teknik Alpha Cronbach dengan menggunakan bantuan program
SPSS for window ver 22. Keputusan dari dilakukannya uji reliabilitas pada suatu instrumen dapat dikatakan reliabel apabila $\mathrm{r}=>0,361$ sehingga dapat dikatakan reliable. hasil reliabilitas dari angket instrument kemampuan literasi digital orang tua anak usia dini di Kecamatan Tampan Kota Pekanbaru Provinsi Riau yang terdiri dari 23 item memperoleh 0,905 yang mana jika nilai tersebut dikonsultasikan dengan $\mathrm{r}$ tabel (untuk 40 responden) maka $r$ hitung $>r$ tabel atau $0,905>0,361$. maka dapat disimpulkan bahwa instrument kemampuan literasi digital orang tua anak usia dini di Kecamatan Tampan Kota Pekanbaru Provinsi Riau reliable. Analisis data dilakukan dengan menggunakan rumus persentase :

Keterangan :

$$
\mathrm{P}=\frac{f}{N} \times 100 \%
$$

$$
\begin{array}{ll}
\mathrm{P} & =\text { Presentase Yang Dicari } \\
\mathrm{f} & =\text { Frekuensi Data } \\
\mathrm{N} & =\text { Jumlah Sampel } \\
100 \% & =\text { Bilangan Tetap }
\end{array}
$$

(Sudjiono, 2010)

Dalam menentukan kategori penilaian yang akan digunakan untuk dapat menentukan kategori yang sesuai untuk kemampuan literasi digital orang tua yang memiliki Anak Usia Dini di Kecamatan Tampan Kota Pekanbaru Provinsi Riau adalah sebagai berikut:

$81 \%-100 \%=$ sangat baik

$61 \%-80 \%=$ baik

$41 \%-60 \%=$ sedang atau cukup

$21 \%-40 \%=$ rendah

$0 \%-20 \%=$ sangat rendah

\section{HASIL DAN PEMBAHASAN}

Berdasarkan dari tabel distribusi data responden penelitian yang merupakan para orang tua yang memiliki anak usia dini di Kecamatan Tampan 
Kota Pekanbaru Riau, sebagian besar Orang tua berada pada usia antara 31 - 35 tahun yang kebanyakan memiliki anak usia dini yang berumur antara 4 - 5 tahun dan sebagaian besar merupakan tamatan SMA dan hanya sekitar $20 \%$ merupakan tamatan S1.

Untuk fasilitas alat digital yang dimiliki orang tua anak usia dini dirumah adalah sebagai berikut:

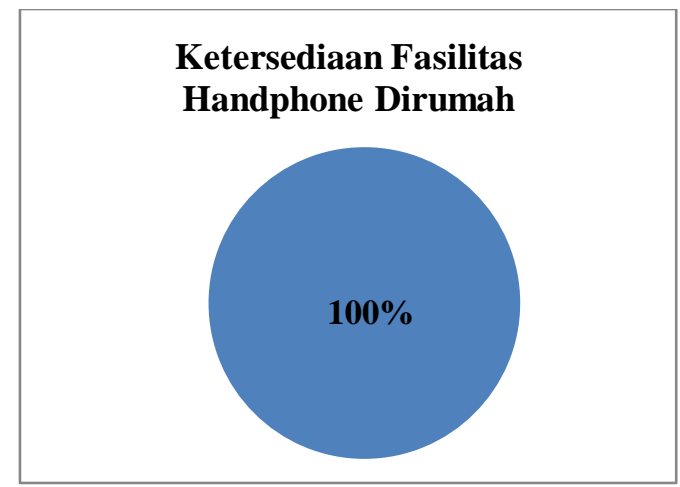

Gambar 1. Ketersediaan perangkat handphone yang dimiliki oleh orang tua anak usia dini dirumah

Berdasarkan Gambar 1 pada diagram diatas maka terlihat bahwa sebanyak 40 orang tua atau dengan persentase $100 \%$ menjawab memiliki perangkat Handphone dirumah.

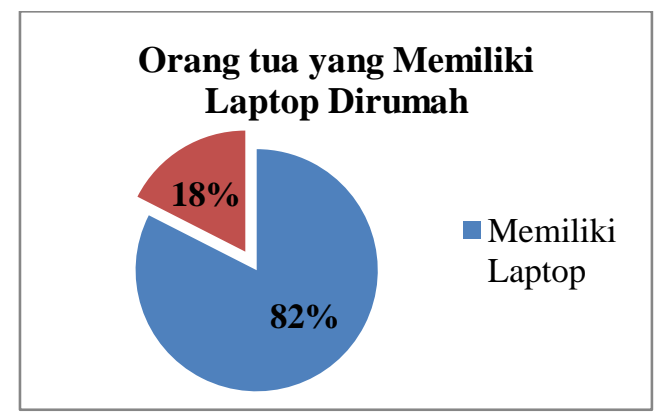

Gambar 2. Adanya ketersediaan fasilitas alat digital Laptop yang dimiliki oleh orang tua anak usia dini dirumah
Dari Gambar 2 maka dapat dilihat bahwa sebanyak $82 \%$ orang tua memiliki laptop dirumah sedangkan sebanyak $18 \%$ sisanya tidak memiliki laptop.

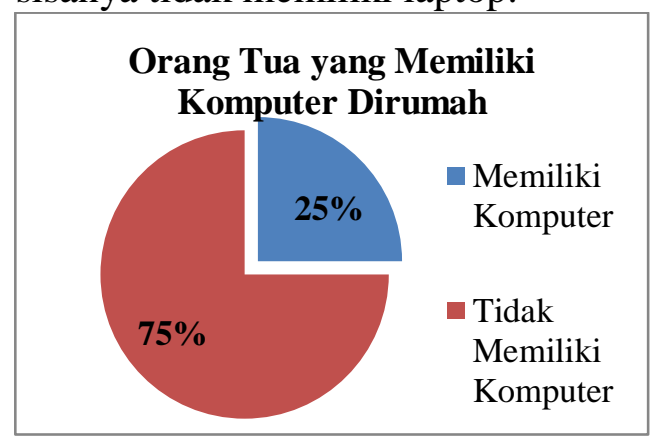

Gambar 3. Adanya ketersediaan fasilitas alat digital Komputer yang dimiliki oleh orang tua anak usia dini dirumah

Dari Gambar 3 dapat dilihat bahwa sebanyak $25 \%$ orang tua memiliki perangkat komputer dirumahnya, sedangkan sebanyak $75 \%$ mengisi tidak memiliki komputer.

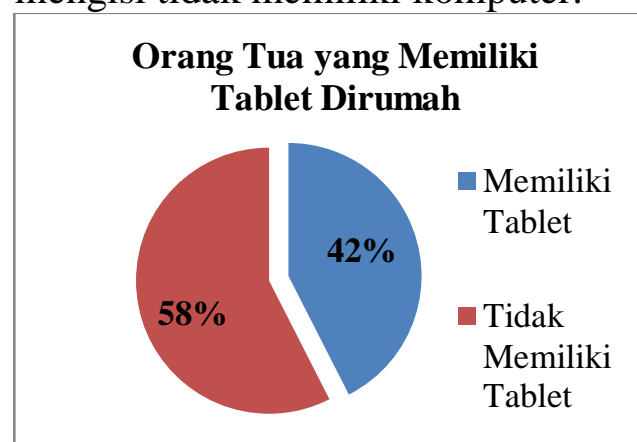

Gambar 4. Adanya ketersediaan fasilitas tablet yang dimiliki orang tua di rumah

Dari Gambar 4 terlihat bahwa sebanyak $42 \%$ orang tua menjawab memiliki tablet dirumah, sedangkan sebanyak $58 \%$ menjawab tidak memiliki tablet. 


\section{Analisis kemampuan Literasi Digital Orang Tua Anak Usia Dini}

Hasil analisis data kemampuan literasi digital orang tua anak usia dini di Kecamatan Tampan, Kota Pekanbaru Riau yang telah di dapatkan dengan menyebarkan kuesioner yang memiliki sebanyak 23 item pernyataan dengan 5 alternatif jawaban dengan menggunakan Teori instant digital competence assessment (Idca) sebagai instrumen penelitian yang terdapat 3 Dimensi kemampuan literasi digital yaitu :

1. Dimensi teknologi terbagi atas mengenali masalah teknologi, mengidentifikasi antarmuka dan memilih solusi yang paling sesuai untuk digunakan pada teknologi.

2. Dimensi kognitif terbagi atas berurusan dengan teks (meringkas, mewakili, menganalisis), mengatur data, mengevaluasi informasi yang relevan dan mengevaluasi keandalan dari informasi yang di dapat.

3. Dimensi Etika terbagi atas melindungi diri sendiri, saling menghormati di internet dan memahami adanya pengertian terhadap sosial dan ketimpangan teknologi.

\begin{tabular}{cccccc} 
Tabel 3. & $\begin{array}{l}\text { Distribusi } \\
\text { Kemampuan }\end{array}$ & $\begin{array}{r}\text { Frekuensi } \\
\text { Literasi }\end{array}$ \\
\multicolumn{4}{c}{$\begin{array}{c}\text { Digital } \\
\text { Dimensi } \\
\text { Dimensi }\end{array}$} & $\begin{array}{r}\text { Orang } \\
\text { Deknologi }\end{array}$ & $\begin{array}{r}\text { Tua } \\
\text { Pada Sub }\end{array}$ \\
\hline Sub Dimensi & N & $\begin{array}{c}\text { Sko } \\
\text { r }\end{array}$ & $\%$ & Ket \\
\hline $\begin{array}{c}\text { Mengenali } \\
\text { masalah } \\
\text { teknologi }\end{array}$ & 80 & 25 & 31 & Rendah \\
$\begin{array}{c}\text { Mengidentifikas } \\
\text { i antar muka }\end{array}$ & 12 & 35 & 29 & Rendah
\end{tabular}

\begin{tabular}{ccccc}
$\begin{array}{c}\text { Memilih solusi } \\
\text { yang paling } \\
\text { sesuai untuk } \\
\text { teknologi } \\
\text { tersebut }\end{array}$ & 80 & 27 & 34 & Rendah \\
\hline Total & $\begin{array}{c}\mathbf{2 8} \\
\mathbf{0}\end{array}$ & $\mathbf{8 7}$ & $\mathbf{3 1}$ & Rendah \\
\hline
\end{tabular}

Sumber: Data olahan, 2020

Dari Tabel 3 dapat dilihat bahwa kemampuan literasi digital orang tua anak usia dini di Kecamatan Tampan Kota Pekanbaru Riau pada dimensi teknologi mendapatkan hasil persentase sebanyak $31 \%$ dan dapat dikategorikan dalam kategori rendah. Dari 23 item yang dibagikan kepada orang tua telah didapatkan jawaban dari instrument penelitian. Pada instrument penelitian yang digunakan dimensi teknologi dapat terbagi atas 3 sub dimensi yaitu :

1. Mengenali masalah teknologi. mendapat persentase sebanyak $31 \%$ yang masuk kedalam kategori rendah. Pada sub menu ini memiliki 2 item pernyataan yaitu :

a. Mencari tahu terlebih dulu, sebelum membawa handphone atau laptop yang rusak ketempat service.penyataan ini mendapat skor 12 dengan persentase sebanyak 30\% dan masuk dalam kategori rendah.

b. Mengetahui mengapa internet (wifi) tidak dapat tersambung ke perangkat digital. Pernyataan ini mendapat skor 13 dengan persentase $32,5 \%$ yang termasuk dalam kategori rendah.

2. Mengidentifikasi antar muka, mendapatkan skor sebanyak 35 dengan persentase $29 \%$. pada sub menu ini memiliki 3 item pernyataan sebagai berikut : 
a. Mencari tahu masalah pada handphone melalui youtube atau google, mendapat skor sebanyak 14 dengan persentase sebesar 35 $\%$ dan masuk dalam kategori rendah.

b. Mencoba langsung tutorial yang ada di youtube untuk mengetahui kerusakan pada $\mathrm{Hp}$, mendapat skor sebanyak 16 dengan persentase sebesar $40 \%$ dan masih dalam kategori rendah.

c. Melihat langsung kerusakan atau masalah pada Hp, Laptop atau komputer, mendapat skor 5 dengan persentase sebesar $12,5 \%$ dalam kategori rendah.

3. Memilih solusi yang paling sesuai. mendapatkan skor sebanyak 27 dengan persentase $34 \%$. pada sub menu ini memiliki 2 item pernyataan sebagai berikut :

a. Mengaktifkan anti virus pada handphone, laptop atau komputer, mendapat skor 16 dengan persentase sebesar $40 \%$ di kategori rendah.

b. Mengabaikan kerusakan yang ada pada handphone, laptop atau komputer, mendapat skor sebanyak 11 dengan persentase 27,5\% dikategori rendah.

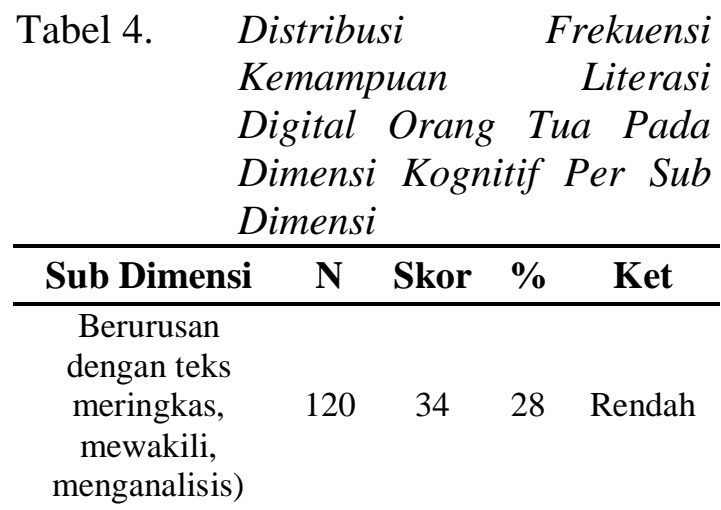

\begin{tabular}{ccccc}
$\begin{array}{c}\text { Mengatur data } \\
\text { Mengevaluasi }\end{array}$ & 120 & 32 & 27 & Rendah \\
$\begin{array}{c}\text { Informasi yang } \\
\text { relevan }\end{array}$ & 120 & 29 & 24 & Rendah \\
$\begin{array}{c}\text { Mengevaluasi } \\
\text { keandalan } \\
\text { informasi }\end{array}$ & 120 & 37 & 31 & Rendah \\
\hline Total & $\mathbf{5 2 0}$ & $\mathbf{1 4 0}$ & $\mathbf{2 7}$ & Rendah \\
\hline
\end{tabular}

Sumber : Data olahan, 2020

Dari tabel frekuensi kemampuan literasi digital orang tua anak usia dini di Kecamatan Tampan Kota Pekanbaru Riau pada dimensi kognitif dapat dilihat bahwa persentase kemampuan orang tua masih rendah yaitu dengan total $27 \%$ saja. Pada instrument penelitian yang digunakan dimensi teknologi dapat terbagi atas 4 sub dimensi yaitu:

1. Berurusan dengan teks, mendapat skor sebanyak 34 dari 120 dengan persentase sebesar $28 \%$ dan dikategorikan rendah. Pada sub dimensi ini terdapat 3 item pernyataan yaitu :

a. Mencari tahu berita terkini yang ada di internet sebagai pengganti surat kabar (dari youtube, google atau website), mendapat skor sebanyak 9 dengan persentase sebesar 22,5\% dan masuk dalam kategori rendah

b. Mencari dan menemukan bahanbahan pembelajaran yang dapat digunakan dan menyenangkan untuk anak, mendapat skor 12 dengan persentase sebesar $30 \%$ masuk di kategori rendah.

c. Menggunakan internet untuk berbagai tutorial, mendapat skor sebanyak 13 dengan persentase $32,5 \%$ di kategori rendah. 
2. Mengatur Data, memperoleh skor sebanyak 32 dari 120 dengan persentase sebesar $27 \%$ dan masuk dalam kategori rendah. Dalam sub dimensi terdapat 3 item pernyataan yang masing-masing item memperoleh persentase sebesar 25 $27 \%$ dam masih di kategori rendah.

3. Mengevaluasi Informasi yang relevan, memperoleh skor sebanyak 29 dari 120 dengan persentase sebesar $24 \%$ dan masuk dalam kategori sedang. Dalam sub dimensi ini terdiri atas 3 item pernyataan yang masuk dalam kategori rendah.

4. Mengevaluasi keandalan informasi, mendapar skor sebanyak 37 dari 120 total skor dengan persentase sebesar $31 \%$ di kategori rendah. Pada sub dimensi ini terdapat 3 kategori berbeda yaitu sebesar $70 \%$ di kategori baik, $45 \%$ di kategori sedang dan $27,5 \%$ di kategori rendah.

Tabel 5. Distribusi Frekuensi

Kemampuan Literasi Digital Orang Tua Pada Dimensi Etika Per Sub Dimensi

\begin{tabular}{|c|c|c|c|c|}
\hline Sub Dimensi & $\mathbf{N}$ & Skor & $\%$ & Ket \\
\hline $\begin{array}{l}\text { Melindungi diri } \\
\text { sendiri dan } \\
\text { orang lain }\end{array}$ & 120 & 47 & 39 & Rendah \\
\hline $\begin{array}{c}\text { Saling } \\
\text { menghormati di } \\
\text { internet }\end{array}$ & 40 & 32 & 80 & Baik \\
\hline Total & 160 & 79 & 49 & Sedang \\
\hline
\end{tabular}

Sumber : Data olahan, 2020

Dari tabel frekuensi kemampuan literasi digital orang tua anak usia dini di Kecamatan Tampan Kota Pekanbaru Riau pada dimensi Etika dapat dilihat bahwa persentase kemampuan orang tua sudah cukup atau sedang yaitu dengan persentase $49 \%$. Pada instrument penelitian yang digunakan dimensi Etika dapat terbagi atas 2 sub dimensi yaitu :

1. Melindungi diri sendiri dan orang lain, mendapatkan skor sebanyak 47 dari 120 total skor dengan persentase sebesar $39 \%$. Pada sub dimensi ini terdapat 3 item pernyataan yaitu yang secara keseluruhan berada dalam kategori sedang atau cukup dengan persentase sebesar $45 \%$.

2. Saling menghormati di internet, mendapat skor sebanyak 32 dari 40 skor total dengan memiliki 1 item pernyataan dengan persentase tertinggi yaitu $80 \%$ dan masuk dalam kategori Baik.

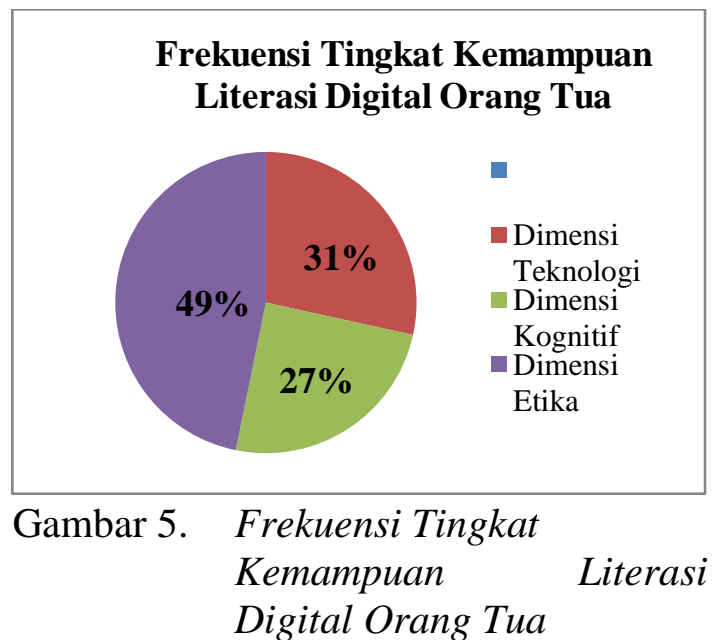

Dari tabel di atas terlihat pada Dimensi Teknologi hasil jawaban dari responden yaitu orang tua anak usia dini yang dipilih secara acak sebanyak 40 orang adalah $31 \%$ yang mana berarti kemampuan literasi digital orang tua anak usia dini pada dimensi teknologi masih rendah. Untuk kemampuan literasi digital orang tua pada dimensi kognitif juga masih rendah yaitu hanya sebesar 
$27 \%$ dan untuk kemampuan literasi digital orang tua pada dimensi etika memperoleh nilai sedang atau cukup dengan pesentase $49 \%$. Maka dari tabel distribusi frekuensi tersebut maka dapat disimpulkan kemampuan literasi digital orang tua anak usia dini di Kecamatan Tampan Kota Pekanbaru Provinsi Riau adalah masih berada dikategori Rendah dengan persentase $31 \%$.

\section{Pembahasan}

Berdasarkan penelitian yang telah peneliti lakukan, maka dapat diketahui secara menyeluruh bahwa dari 40 responden yang telah mengisi 23 item dan pertanyaan yang terdapat dalam kuesioner penelitian yang disebarkan secara online, maka dapat dilihat mayoritas responden untuk penelitian kemampuan literasi digital orang tua adalah berada pada usia antara 31-35 tahun dengan persentase sebanyak $70 \%$, yang mana sebanyak $80 \%$ merupakan lulusan SMA dan sisanya merupakan lulusan S1. Selain itu sebagian besar responden yang merupakan para orang tua kebanyakan adalah yang memiliki anak usia dini 4 dan 5 tahun yang tinggal di Kecamatan Tampan Kota Pekanbaru Riau.

Dari hasil analisis data yang peneliti lakukan dengan menggunakan teori Idca sebagai instrumen penelitian, maka diketahui bahwa kemampuan literasi digital orang tua anak usia dini di Kecamatan Tampan Kota Pekanbaru Riau masih berada pada kategori rendah yaitu dengan persentase $31 \%$ dengan skor sebanyak 288 dari 920, yang artinya pada 3 dimensi yang menjadi indikator untuk mengetahui kemampuan literasi digital kemampuan literasi digital orang tua anak usia dini berada dalam kategori yang rendah.

Pada kemampuan literasi digital dalam dimensi teknologi, kemampuan literasi orang tua anak usia dini yang tinggal di Kecamatan Tampan Kota Pekanbaru Riau masih berada di kategori rendah dengan persentase sebesar $31 \%$. pada sub dimensi teknologi yaitu mengenali masalah teknologi, salah satunya pada pernyataan "mencari tahu terlebih dulu sebelum membawa perangkat digital ke tempat service" memiliki nilai persentase $30 \%$ dan juga masuk kedalam kategori rendah sama dengan 3 pernyataan yang lain. Pada sub dimensi teknologi selanjutnya yaitu memilih solusi yang paling sesuai jika terjadi kerusakan atau gangguan pada perangkat digital juga berada dalam kategori rendah dengan persentase $34 \%$.

Dalam hal ini orang tua seharusnya dapat lebih berusaha untuk memahami dan mengikuti alur perkembangan zaman dengan yang semakin berkembang dan semakin berkembangnya teknologi digital yang dapat digunakan untuk membantu menunjang berbagai kebutuhan informasi dan komunikasi sehari - hari, Pernyataan ini sejalan dengan penelitian yang dilakukan (Novianti, R, \& Garzia, M, 2020) yang menyatakan bahwa orang tua memiliki peran yang penting dalam penggunaan gadget pada anak.

(Fatmawati N. I., 2019) menyebutkan bahwa orang tua wajib melakukan upgrade atau meningkatkan kemampuan diri dengan informasi global terkini mengenai dunia dan tren anak zaman sekarang. orang tua perlu maju satu tingkat setidaknya setara dengan pengetahuan anak, dengan itu orang tua dapat mengontrol aktivitas anak dalam 
menggunakan media digital. Pada dimensi kognitif kemampuan literasi orang tua anak juga masih berada pada kategori rendah dengan mendapat persentase paling rendah diantara dimensi yang lain yaitu sebesar 27\% dengan perolehan skor sebesar 140 dari 520. Padahal pada dimensi kognitif memiliki peran yang sangat besar untuk dapat membantu dan meningkatkan proses belajar anak selama masa pandemik covid ini yang mengharuskan anak untuk melakukan pembelajaran daring dan memiliki waktu yang banyak di rumah, hal ini sejalan dengan penelitian (Suci Lestari, dkk, 2018) yang mengatakan bahwa pencapaian pelajar akan meningkat jika orang tua mengambil peran aktif dalam pendidikan anak - anak mereka. orang tua harus ikut terlibat langsung dalam pendidikan dan kegiatan anak - anaknya agar prestasi dan mentalnya dapat terus berkembang dengan baik.

Dari hasil analisis data pada dimensi kognitif terdapat 4 sub dimensi yang juga memperoleh skor yang termasuk kedalam kategori rendah yaitu Berurusan dengan teks (meringkas, mewakili, menganalisis) hanya mendapatkan skor sebanyak 34 dari 120 dan termasuk kedalam kategori rendah dengan persentasi sebesar $28 \%$. Hal yang sama juga ditemui dalam sub dimensi mengatur data yang juga memperoleh skor sebanyak 32 dari 120 skor ideal dengan persentase sebesar 27\%. Dalam melakukan suatu evaluasi yang relevan responden hanya mendapatkan skor sebanyak 29 dari 120 dengan persentase sebesar 24\% saja dan yang terakhir dalam sub dimensi kognitif yaitu mengevaluasi keandalan informasi, yang mana pada saat memperoleh informasi penting bagi kita untuk mengetahui terlebih dahulu apakah informasi yang diperoleh tersebut adalah dari sumber terpercaya dan teruji kebenarannya memperoleh skor sebanyak 37 dari 120 skor ideal dengan persentase sebesar $31 \%$ dan termasuk dalam kategori rendah.

Dari hasil analisis data pada dimensi etika, diperoleh total skor 79 dari 160 skor ideal dengan persentase $49 \%$ dan masuk dalam kategori sedang. namun dalam 2 sub dimensi etika terdapat perbedaan perolehan skor oleh responden yaitu pada sub dimensi melindungi diri sendiri dan orang lain memperoleh skor 47 dari 120 yang merupakan skor ideal dengan presentase sebesar 39\% dan masuk dalam kategori rendah, dalam sub dimensi tersebut terdapat pernyataan "Melakukan pengawasan pada anak saat sedang menggunakan gadget" yang mana pada penelitian ini hanya mendapat skor sebanyak 18 dari skor ideal sebesar 40 dan mendapat persentase sebesar $27,5 \%$. yang artinya dari 40 orang tua hanya sebanyak 18 orang tua yang sangat sering mengawasi anaknya pada saat bermain gadget sedangkan yang lainnya menjawab hanya sekedar sering dan kadang-kadang mengawasi anak pada saat bermain gadget.

Dari hasil penelitian (Maria, I \& Novianti, R, 2020) juga ditemukan bahwa anak yang selalu menggunakan gadgetnya lebih dari 10 jam sehari ada sebanyak $21,3 \%$ yang menyatakan sering, 51,1\% yang menyatakan kadang kadang, sebanyak $12,8 \%$ menyatakan hampir tidak pernah dan sebanyak $9,6 \%$ yang menyatakan tidak pernah menggunakan gadget. ini sejalan dengan hasil penelitian yang dilakukan oleh 
(Maria, I \& Novianti, R, 2020) bahwa dari Penggunaan gadget yang berlebihan pada anak akan berdampak negatif karena dapat menurunkan daya konsentrasi dan meningkatkan ketergantungan pada anak untuk mengerjakan berbagai hal yang seharusnya dapat anak lakukan sendiri.

Hasil penelitian yang telah dilakukan oleh peneliti maka dapat di simpulkan bahwa dengan Memiliki kemampuan literasi digiral akan sangat memudahkan untuk mempermudah dan di terapkan dalam berbagai kehidupan sehari - hari. orang tua dalam hal ini sebaiknya mampu untuk mengembangkan kemampuan literasi digitalnya yang tidak hanya berguna bagi dirinya sendiri namun juga untuk keluarga terutama anak usia dini karna dengan memiliki kemampuan tersebut diharapkan orang tua dapat menggunakan alat digital dengan berbagai fitur kemajuan seiring perkembang zaman yang dapat memberi manfaat tidak hanya untuk pribadi tapi juga untuk anak-anak. Hal ini sejalan dengan hasil penelitian (Tarma, Maya Oktaviani, 2019) yang menyebutkan bahwa hasil dari penelitiannya menunjukkan bahwa internet dapat memberikan manfaat bagi masyarakat saat digunakan dengan bijak.

Maka dari itu untuk dapat meningkatkan kemampuan literasi digital orang tua pada ketiga dimensi tersebut maka sangat diperlukan suatu kegiatan yang dapat dilakukan oleh tenaga pendidik maupun lembaga pendidikan terkait untuk melakukan sosialisasi mengenai betapa pentingnya memiliki kemampuan literasi digital sehingga nantinya orang tua dapat meningkatkan persentase kemampuan literasi digitalnya. Ini sejalan dengan penelitian yang dilakukan oleh (Novianti, R, dkk, 2020) bahwa dengan adanya kegiatan pengabdian kepada masyarakat dengan diadakannya sosialisasi, maka tujuan kegiatan pun tercapai dengan adanya peningkatan yang signifikan.

\section{KESIMPULAN}

Berdasarkan dari hasil penelitian yang telah di lakukan maka dapat di simpulkan bahwa kemampuan literasi digital yang dimiliki oleh orang tua anak usia dini di Kecamatan Tampan Kota Pekanbaru Riau adalah berada pada kategori " rendah " yaitu dengan persentase sebesar $31 \%$ yang mana memperoleh skor sebanyak 306 sebagai skor faktual dari 960 total skor ideal. Sedangkan untuk pembagian kemampuan literasi digital berdasarkan dimensi beserta sub dimensi yang ada di dalamnya yaitu sebanyak 3 dimensi instrument penelitian maka dapat di simpulkan pada dimensi teknologi berada dalam kategori " rendah " dengan persentase sebanyak $31 \%$ dengan perolehan skor fatual sebanyak 87 dari 280 total skor ideal yang seharusnya didapatkan. Untuk dimensi kognitif sendiri mendapat persentase paling rendah diantara dua dimensi yang lain yaitu sebesar $27 \%$ dan berada dalam kategori "rendah" dengan skor factual sebesar 140 dari 520 total skor ideal dan yang terakhir ialah pada dimensi etika adalah satu - satunya dimensi yang berada pada kategori " sedang atau cukup " dengan persentase sebesar $49 \%$ dengan perolehan skor factual sebanyak 79 dari 160 total skor ideal.

Berdasarkan dari hasil penelitian yang telah dilakukan, maka peneliti memberikan beberapa saran yang 
nantinya diharapkan dapat dijadikan masukan bagi pihak - pihak terkait yang berhubungan dengan pendidikan anak usia dini dan kemampuan literasi digital yaitu:

1. Bagi orang tua yang memiliki anak usia dini agar dapat lebih menyadari pentingnya kemampuan literasi digital tersebut. Dengan memiliki kemampuan literasi digital yang baik diharapkan nantinya orang tua dapat membimbing anak untuk dapat memanfaatkan teknologi digital sebaik-baiknya seperti mencari sumber belajar dan permainan yang edukatif dan menarik untuk anak.

2. Bagi pendidik anak usia dini juga diharapkan mampu mengajarkan anak tentang pemanfaatan media digital untuk kehidupan sehariharinya. guru dapat mengenalkan aplikasi pintar kepada anak pada saat disekolah sehingga diharapkan nantinya anak dapat menggunakan gadgetnya dengan sebaik-baiknya.

3. Bagi Kemendikbud atau lembaga terkait lainnya khusunya daerah Riau untuk dapat melakukan sosialisasi mengenai seberapa pentingnya gerakan literasi digital bagi kehidupan sehari-hari pada zaman yang semakin berkembang pesat, dengan melakukan gearakan literasi digital yang tidak hanya di sosialisasikan di sekolah - sekolah namun juga di tempat lingkungan keluarga yang mana dalam hal ini lingkungan keluarga adalah yang paling dekat dengan anak.

\section{DAFTAR PUSTAKA}

Candra, P. (2013). Penggunaan internet pada anak- anak sekolah usia 6-
12 tahun. Journal UNAIR, Vol. 1 No. 2, Februari 2013.

Davidson, C. (2012). Seeking the green basilisk lizard: Acquiring digital literacy practices in the home. Journal of Early Childhood Literacy, Vol. 12. No. 1: 24-45.

Fatmawati, N. I. (2019). Literasi Digital, Mendidik anak di Era Digital Bagi Orang Tua Milenial. Jurnal Politik Sosial dan Kemasyarakatan, Vol 11 No 2 : 120-131.

Kurnia, Novi, Engelbertus Wendratama. (2017). Literasi Digital Keluarga. Teori dan Pendampingan Orang Tua Terhadap Anak Dalam Berinternet. Yogyakarta: Center for digital society.

Maria, I \& Novianti, R. (2020). The Effects Of Using Gadgets During The Covid-19 Pandemic On Children's Behavior. Atfaluna : Journal Of Islamic Early Childhood Education, 3 (2), 7481.

Novianti, Hukmi \& Maria, I. (2019). Generasi Alpha-Tumbuh Dengan Gadget Dalam Genggaman. Jurnal Educhild : Pendidikan Dan Sosial, 8 (2), 65-70.

Novianti, R, \& Garzia, M. (2020). Penggunaan Gadget Pada Anak: Tantangan Baru Orang Tua Milineal. Jurnal Obsesi: Jurnal Pendidikan Anak Usia Dini, 4 (2), 1000-1010.

Novianti, R, dkk. (2020). Meningkatkan Pengetahuan Orang Tua Dalam Mendidik Anak Di Era Digital Di Kecamatan Koto Gasib Kabupaten Siak Privinsi Riau. 
Riau Journal Of Empowerwoment, 3 (3), 183-19.

Suci Lestari, dkk. (2018). Pengukuran Kemampuan Literasi Digital Orang Tua Menggunakan Instant Digital Competence Assessment (Instant DCA). Jurnal Ilmu Perpustakaan dan Informasi, Vol 3, No 2 : 93-105.

Sucipto \& Nuril, H. (2016). Pola bermain anak usia dini di era gadget siswa PAUD Mutiara Bunda Sidoarjo. Jurnal Ilmiah Fenomena, Vol. 3 No. 6: 274347.

Tarma, Maya Oktaviani. (2019). Pengaruh Penggunaan Internet Terhadap Literasi Keluarga. Vol 33 No. 2 : 79-83. 